\title{
NOWOŁACIŃSKI PRZEKŁAD DZIEt ŚW. JANA OD KRZYŻA W KONTEKŚCIE EUROPEJSKIEJ LATINITAS DOBY RENESANSU I BAROKU
}

\section{Status QuaEstionis}

Nowoczesne przekładoznawstwo narodziło się w latach 60. poprzedniego wieku. Chociaż o sztuce translacji pisali już poeci greccy, mówcy rzymscy, nie wspominając o złotych wiekach przekładu w historii chrześcijaństwa, na czele z takimi mistrzami jak Orygenes czy Hieronim ze Strydonu, zdaniem wielu naukowa teoria przekładu narodziła się dopiero w XX wieku. Zasługą ostatniego zwrotu kulturowego w badaniach nad przekładem (translation studies) jest zarzucenie deskryptywnej teorii na rzecz analizy konkretnych przekładów i rozstrzygnięć ${ }^{1}$. Chodzi o przejście od namysłu nad anachroniczną ekwiwalencją do próby nawiązania kontaktu nie tylko między oryginałem (jego autorem) i czytelnikiem tłumaczenia, ale między dwiema kulturami, dwoma światami. To ożywiło nową dyskusję nad wzajemnym oddziaływaniem systemów literatur narodowych. Tłumaczenie w takiej perspektywie jest jakby polem bitwy i pertraktacji, a tłumacz może zamienić się w imperialistycznego drapieżnika lub ciekawego świata podróżnika².

W takiej optyce trzeba rozpatrywać również problem nowołacińskich tłumaczeń, które powstawały już w późnym średniowieczu. Przekłady na łacinę dzieł literatury narodowej były pomostami do nowego świata, pomagając ustalić chwiejne i niespo-

1 J.S. Holmes, The name and nature of translation studies, w: The Translation Studies Reader, red. L. Venuti, London-New York 2004, s. 180-192.

2 Zob. L. VenuT, The Scandals of Translation: Towards an ethics of difference, London-New York 1998, s. 86. 
kojne sensy nowych i żywych słów w krzepnących językach Europy. Stały się kanatem komunikacji między kulturami, otwartymi oknami na to, co inne3.

Dorobek twórczy Andrzeja Brzechwy (1584-1640), pierwszego polskiego karmelity bosego, to w większości łacińskie kazania i rękopiśmienne utwory ascetyczne. Ostatnie 15 lat życia spędził na przygotowaniu przekładu z hiszpańskiego na łacinę pism św. Jana od Krzyża. Niestety, do tej pory nie ukazało się żadne szerokie studium na temat jego życia i dzieła, opracowujące w sposób krytyczny również jego przekład na język łaciński ${ }^{4}$. Pamięć o tym filologu par excellence zawdzięczamy jedynie przepisywanym nekrologom w zbiorach takich jak Decore Carmeli Religiosi. W XX wieku czytamy o Brzechwie jedynie w Polskim stowniku biograficznym, akcydentalnie w opracowaniach historycznych Benignusa Wanata OCD, Honorata Gila OCD i Arkadiusza Smagacza ${ }^{5}$. Te same powielane informacje rozsiane są po czasopismach katolickich, w tym przed wszystkim w „Głosie Karmelu”. W literaturze naukowej Andrzeja Brzechwę można odnaleźć w kontekście jego bardziej znanego krewnego, opata tynieckiego o tym samym imieniu i nazwisku. Ze względu na pochodzenie szlacheckie Brzechffa (sic) jest odnotowany w herbarzu pod wezwaniem Jastrzębiec ${ }^{6}$.

Mój artykuł ma charakter szkicu, a na celu ma wypełnienie luki w polu badawczym oraz ożywienie studiów nad tym wyjątkowym pisarzem, mówcą i tłumaczem, którego spuścizna została przykryta kurzem czasu. Po przedstawieniu kontekstu historycznego europejskiej i polskiej twórczości nowołacińskiej (ze szczególnym akcentem na poetykę Macieja Kazimierza Sarbiewskiego) chciałbym przybliżyć kilka faktów z życia Brzechwy i przeprowadzić wstępną analizę wybranych fragmentów $z$ jego przekładu dzieł św. Jana od Krzyża. Celem tego artykułu jest umiejscowienie Brzechwy jako tłumacza w polskiej i europejskiej tradycji barokowej neolatinitas ${ }^{7}$.

3 Zob. S. ZABєосK, Od prerenesansu do oświecenia. Z dziejów inspiracji klasycznych w literaturze polskiej, Wrocław 1976, s. 78.

4 Na brak literatury naukowej na temat rozsianych po zakonach przedstawicieli literatury nowołacińskiej skarżył się już Albert Gorzkowski: „Brak nie tylko monografii, która uporządkowałaby i zweryfikowała jednocześnie materiał historycznoliteracki, dokonując tym samym rewindykacji źródeł, lecz nawet syntetycznego szkicu, który mógłby pełnić funkcję filologicznego, krytycznego wstępu do zarysu piśmiennictwa polsko-łacińskiego, chociażby tylko do r. 1543" (A. GoRzKOWSKI, Neolatinitas caduca. Piśmiennictwo nowołacińskie polskiego Renesansu w perspektywie historyczno-literackiej, „Odrodzenie i Reformacja w Polsce” XLII [1998]).

5 Zob. Cz. GIL, Karmelici bosi w Polsce 1605-1655, „Nasza Przeszłość” 48 (1977), s. 1-237; Cztery wieki karmelitów bosych w Polsce (1605-2005), red. A. Ruszała, Kraków 2005; A. SmaGacz, Czterysta lat karmelitów bosych w Lublinie (1610-2010), Lublin 2010; B.J. WANAT, Zakon karmelitów bosych w Polsce, Kraków 1987.

6 Zob. K NiesieCKI, Herbarz polski, t. II, Lipsk 1839, s. 324.

7 Badania twórczości nowołacińskiej mają szeroką bibliografię, przywołuję tylko niektóre ważne tytuły: T. UlewIECz, Sto lat badan filologicznych nad lacinską twórczością humanistyczno-renesansowa w Polsce, w: Wokót Kochanowskiego i jego czasów. Materiały sesji naukowej poświęconej kulturze literackiej Matopolski w dobie renesansu. Kielce, 10-11 pażdziernika 1992, red. M. Garbaczowa, Kielce 1994, s. 7-36; Konterfekty, sylwetki, cienie. Z dziejów filologii w Polsce, Kraków 1997, s. 129; A. Borowski, Literatura Renesansu, w: Wiedza o literaturze i edukacja. Ksiega referatów Zjazdu Polonistów, Warszawa 1995, Warszawa 1996, s. 177-190; J. AxER, Tradycja klasyczna w polskojezycznej 


\section{Z£OTE WIEKI POLSKIEJ NEOLATINITAS}

\subsection{Wiek wojen, przemian i tragedii}

W XVII stuleciu Europa przeżywała okres gwałtownych konwulsji i cywilizacyjnych przesileń. Przemiany te doprowadzić miały do powstania na kontynencie państw typu nowożytnego i wykreowania nowej, przejmującej wizji świata wyrażonej w dramatycznym stylu baroku. W środkowo-wschodniej części Europy nastąpiło wówczas upowszechnienie zdobyczy renesansu, które dopiero teraz stawały się własnością edukowanych w kolegiach jezuickich „panów braci” szlachty ${ }^{8}$.

Rzeczpospolita była wtedy drugim co do wielkości krajem Europy, liczącym w pierwszej połowie XVII wieku prawie $1000000 \mathrm{~km}^{2}$ i obejmującym prócz ziem etnicznie polskich także Litwę, Białoruś i Ukrainę. Stabilna w poprzedniej epoce struktura polityczna i ekonomiczna u progu baroku zaczęła ulegać stopniowemu zachwianiu, by pod koniec okresu zmierzać ku całkowitej ruinie. Wraz ze spadkiem zależności Zachodu od dostaw polskiego zboża skończyły się dla Rzeczypospolitej błogosławione lata prosperity i rosnącego dobrobytu .

U schyłku renesansu łacińską kulturę Polski cechowała daleko idąca współbieżność z duchowym życiem Zachodu. Dzieła Kopernika, Dantyszka, Strusia, Modrzewskiego obiegały Europę, wpisując myśl polską do księgi uniwersalnych osiągnięć zachodniej cywilizacji. W XVII wieku drogi rozwoju kultury polskiej i zachodnioeuropejskiej miały się jednak rozejść. Na Zachodzie kulturę baroku formowały i podtrzymywały wielkie dyskusje literackie i artystyczne, rewolucja naukowa, spory między zwolennikami starożytności i nowożytnikami. W Polsce problemy te nie wywoływały większego oddźwięku, a kształt epoce nadawały głównie ośrodki kultury reformacyjnej i kontrreformacyjnej oraz rodzimy nurt ideowy zwany sarmatyzmem ${ }^{10}$.

Tendencje, jakie zaznaczyły się w kulturze polskiej u progu baroku, miały jednak swe podłoże także w ogólnym przesileniu, które ogarnęło świadomość europejską po załamaniu się renesansowego humanizmu. Upadł on na skutek straszliwych doświadczeń „wieku wojen, przemian i tragedii” ${ }^{11}$ - jak określił XVII stulecie Abraham Cowley (1618-1667), jeden z metafizycznych poetów tej doby. Nowy, przetopiony w ogniu ruchów religijnych humanizm baroku uczynił ośrodkiem swej myśli

poezji renesansowej a mechanizmy odbionu tej poezji, „Pamiętnik Literacki” LXXV (1984), z. 2, s. 207 i n.; Le tradizioni classische nella letteratura polacca. Dal Cinquecento alla prima guerra mondiale, „Ricerche Slavistische” XXXIX-XL (1992-1993), z. 2, s. 8 i n.; M. CrtowsKa, Studia Neolatina. Pięć odczytów, Wrocław 1983, rozdz. 1 i 2.

8 Zob. Społeczeństwo staropolskie. Studia i szkice, red. A.Wyczański, t. 2, Warszawa 1980, s. 12.

9 Zob. „Barok. Historia-Literatura-Sztuka” 1994, nr 1.

10 Zob. W. Janicki, Humanizm i sarmatyzm w mitologii i rzeczywistości historycznej. Przeciw uproszczeniom, „Życie i Myśl” 1984, nr 3, s. 74-78.

11 Cyt. za: T. CeGIELSKI, Ordo ex chao. Wolnomularstwo i światopogladowe kryzysy XVII i XVIII wieku, Warszawa 1994, s. 39. 
dramat człowieka, który musiał szukać własnych wyborów egzystencjalnych w samotnym dialogu z Bogiem.

Impulsy tej duchowej konwersji płynęły do Polski głównie z Italii (potem także z Francji) - skąd rozchodziły się zresztą na całą katolicką Europę. W Rzeczypospolitej ich recepcja była jednak odmienna niż na Zachodzie. Wiek XVII nie był bowiem dla Polski czasem owocnej twórczości - przeciwnie, stał pod znakiem wyniszczających wojen i niezwykle krwawych rebelii. Zmagania z prawosławną Moskwą i Kozaczyzną, luterańską Szwecją i muzułmańską Turcją przypieczętowały identyfikację polskości z rzymskim katolicyzmem, skłaniając naród do „poszukiwania sensu zbiorowego losu raczej w religijnej egzaltacji, niż w twórczej ekspresji”"12.

A jednak to właśnie wówczas wpływy latinitas polskiej sięgnęły dalej na wschód niż kiedykolwiek przedtem i potem. Dość powiedzieć, że cywilizacyjna misja Polski na kresach doprowadziła w XVII wieku nie tylko do latynizacji litewsko-ukraińskiego pogranicza, lecz także tchnęła rzymskiego ducha na słowiańsko-prawosławną Moskwę i Multany ${ }^{13}$.

\subsection{Język kontrreformacji}

W kulturze polskiego renesansu nie było zasadniczo konfliktów między grecko-rzymską tradycją a chrześcijaństwem. Owszem, antyk posiadał dużą autonomię ideową, a klasyczna łacina sama w sobie miała wartość niezależną od jej praktycznej przydatności. W dobie baroku za sprawą kontrreformacji - czyli prądu katolickiej sanacji chrześcijaństwa - tradycja antyczna została poddana kontroli i kulturowej chrystianizacji.

Uchwały Soboru Trydenckiego (1545-1563), będące odpowiedzią Stolicy Piotrowej na kryzys wywołany przez reformację, stworzyły program odnowy katolicyzmu. Miała się ona dokonać poprzez konsolidację Kościoła wokół doktryny grzechu i odpuszczenia, sakramentów, czyśćca i odpustów oraz łacińskojęzycznej liturgii. Kontrreformacja czerpała swoje słownictwo z chrześcijańskiego humanizmu, zaś jej "gramatyką" było trydenckie wyznanie wiary (1564) i Katechizm rzymski (1566).

W Rzeczypospolitej, gdzie tradycje tolerancji religijnej nie pozwalały nawracać nikogo siłą, kontrreformacja posługiwała się głównie środkami perswazji i propagandy. W tych warunkach podstawowe znaczenie dla rozwoju kultury baroku w Polce miały spory toczące się wokół uchwalonej przez sejm w 1573 roku tzw. konfederacji warszawskiej, gwarantującej różnowiercom wolność i swobodę wyznania. Nasiliły się one zwłaszcza po oficjalnym przyjęciu przez Kościół polski trydenckich uchwał na synodzie piotrkowskim w $1577 \mathrm{roku}^{14}$.

12 S. Zabeocki, Polsko-łacińskie epicedium renesansowe na tle europejskim, Wrocław 1968, s. 56.

13 Zob. Literatura i instytucje w dawnej Polsce, red. H. Dziechcińska, Warszawa 1994, s. 75.

14 Zob. K. ŁOPATECKI, Organizacja, prawo i dyscyplina w polskim i litewskim pospolitym ruszeniu (do potowy XVII wieku), Białystok 2013, s. 282. 
Jednakże to nie działania administracyjne spowodowały, że zapoczątkowany u schyłku XVI stulecia odwrót od reformacji zmienił się w XVII stuleciu w masowy powrót szlachty do katolicyzmu ${ }^{15}$. Dokonało się to za sprawą tego samego czynnika, który wcześniej zadecydował o sukcesach reformacji - była nim „złota wolność” narodu szlacheckiego.

Wolność ta polegała przede wszystkim na prawie dokonywania wyboru, dlatego tylko perswazja mogła ten wybór sugerować i do niego namawiać. Była to wolność osobista, dlatego dla jednego szlachcica kończyła się tam, gdzie zaczynała się wolność drugiego pana brata. Takie rozumienie aurea libertas ${ }^{16}$ gwarantowało rozładowywanie konfliktów w polemikach i dysputach, bez niebezpieczeństwa rozniecenia wojny religijnej. Postawa taka kształtowała dialogowy charakter polskiej duchowości, czyniąc ją podatną na perswazyjny ton kontrreformacyjnej kultury.

Ojcowie Soboru Trydenckiego trafnie przewidzieli bowiem, że walka o dusze wiernych rozegra się w sferze kultury, a wygra ją ta ze stron, która lepiej zaadaptuje dla swych celów wielką spuściznę humanizmu. Atutem Kościoła okazała się tu łacina, której obecność w rzymskiej liturgii odróżniała społeczność katolicką od protestanckiej. Przywódcy trydenckiej krucjaty dostrzegli w tym jednocześnie szansę konsolidacji wiernych wokół języka i rzymskiej doktryny wiary. Łacina, stając się mową kontrreformacji, dostarczyła jej szermierzom także niezwykle skutecznej broni - antycznej retoryki, z całą jej perswazyjną i uwodzicielską mocą ${ }^{17}$.

Sukces polskiej kontrreformacji nie byłby jednak możliwy bez gorliwego zaangażowania się w nią jezuitów, spośród których wywodzili się główni ideolodzy potrydenckiego katolicyzmu: Stanisław Warszewicki, Jakub Wujek i Piotr Skarga. Pod czujnym okiem ojców z Towarzystwa Jezusowego łacina stała się w epoce baroku drugim, a właściwie trzecim (po polskim i ruskim) językiem Rzeczypospolitej.

\subsection{Antyk w zwierciadle baroku}

Olbrzymi wpływ, jaki szkolnictwo Towarzystwa Jezusowego wywarło na kulturę Rzeczypospolitej, zadecydował także o „jezuickim” kształcie recepcji antyku w polskim baroku. Uwidoczniło się to między innymi w awansie nowych tekstów i nowych autorów rzymskich, których poczytność, za sprawą lektur szkolnych, niepomiernie wzrosła w stosunku do czasów renesansu. Przede wszystkim uległ jednak zmianie sam stosunek do grecko-rzymskiej starożytności, która przestała być wzor-

is Po 1655/1656 roku kalwinizm i luteranizm sprowadzone zostały w Polsce do mało znaczących mniejszości.

16 Złota wolność - potoczne określenie swobód, praw i przywilejów przysługujących szlachcie w Rzeczypospolitej Obojga Narodów.

17 Zob. M. Kosman, Protestanci i kontrreformacja. Z dziejów tolerancji w Rzeczypospolitej XVI-XVIII wieku, Wrocław 1978, s. 143-145. 
cem do naśladowania, a stała się źródłem wiedzy i konceptu, w służbie zbudowania moralnego i cnotliwego życia ${ }^{18}$.

$Z$ „nowych” autorów wielką poczytność zyskał Cezar, który już w końcu XVI wieku był autorem szkolnym. Podziwiano jego zwięzły, rzeczowy styl ${ }^{19}$. W tych okolicznościach Cezar przekroczył mury kolegiów, stając się wzorcem dla ówczesnych pamiętnikarzy, poczynając od słynnej relacji hetmana Stanisława Żółkiewskiego pt. Poczatek i progres wojny moskiewskiej (1612).

Kolejnym odkrytym dzięki szkole pisarzem był Lucjusz Anneusz Seneka (I wiek po Chr. ${ }^{20}$. Ceniono go jako filozofa-moralistę, lecz przede wszystkim fascynował mroczną i okrutną dramaturgią swych tragedii: Heracles jurens (Herakles szalejacy), Troades (Trojanki) czy Phaedra (Fedra), które dostarczały tematów dla scen szkolnych. Barok docenił także współczesnego Senece Marka Anneusza Lukana, autora epopei historycznej Pharsalia, zachwycając się jego kunsztownym i wyszukanym stylem, bliskim manieryzmowi. Dodać do nich można jeszcze Aulusa Persjusza Flakkusa i Decimusa Juniusza Juwenalisa - satyryków rzymskich z okresu cesarstwa, którzy piętnując wady rzymskiego społeczeństwa, dostarczali przykładów wszelkiej maści moralistom ${ }^{21}$.

Istniały dwa zasadnicze modele barokowej recepcji antyku: protestancki i katolic$\mathrm{ki}^{22}$. Ten pierwszy nazwać można pragmatycznym, dostrzegał bowiem użyteczność łaciny przede wszystkim w studiach naukowych i zgłębianiu starożytnej wiedzy. Filip Melanchton i Jan Sturm widzieli w antyku duże walory poznawcze i etyczne, jednakże nie starali się sztucznie łączyć go z moralnością chrześcijańską. Z kolei działający w Lesznie Jan Amos Komeński w ogóle odrzucał lekturę pisarzy antycznych, podważając zarazem autorytet starożytnych w nauczaniu przyrodoznawstwa.

Katolicka recepcja antyku była, rzec można, bardziej metafizyczna. Kontrreformacyjni twórcy nie dostrzegali sprzeczności między pogańskimi tekstami a prawdami wiary chrześcijańskiej. Najczęściej interpretowali bowiem starożytne dzieła alegorycznie, to znaczy wydobywali z nich cząstkę prawdy nadprzyrodzonej ukrytej pod postacią symboli ${ }^{23}$.

18 Por. B. Nadolski, Poezja polska epoki Odrodzenia, w: Odrodzenie w Polsce. Materiaty sesji naukowej PAN 25-30 IX 1953, t. 4, Warszawa 1956, s. 29; Historia literatury, red. J. Ziomek, Warszawa 1956, s. 161 i n.; J. NowaK-DŁużewsKI, Okolicznościowa poezja polityczna w Polsce. Czasy Zygmuntowskie, Warszawa 1966, s. 352-354; J. STaRnawsri, Dzieje wiedzy o literaturze polskiej (do końca wieku XVIII), Wrocław-Warszawa-Kraków-Gdańsk 1984, s. 10 i n.

19 W wieku wojen i rebelii bardziej jednak interesowano się samą batalistyczną tematyką Bellum Gallicum (Wojna galijska) i Bellum civile (Wojna domowa).

20 Zob. T. Sinko, Historia poezji Zaciñskiej humanistycznej w Polsce, w: Dzieje literatury pięknej w Polsce, red. S. Tarnowski, Kraków 1918, s. 171.

21 Zob. Cz. Hernas, Barok, Warszawa 2002, s. 126.

22 Zob. A. Tokarczyk, Protestantyzm, Warszawa 1980, s. 71.

23 Być może dlatego żaden ze starożytnych autorów nie znalazł się na kościelnym Index librorum prohibitorum (Indeks ksiag zakazanych), co nie oznacza, że spuścizna antyku nie podlegała selekcji. 
Wskazówki, jak wykładać i objaśniać dzieła pisarzy antycznych, zawierała Bibliotheca selecta de ratione studiorum (Biblioteka wyborowa zgodna z programem studiow, 1593, 1603, 1607) włoskiego jezuity Antonio Possevino (1533-1611). Autor dowodził w niej, że pisma starożytnych należy wykorzystywać bądź jako wzorce techniki poetyckiej, bądź jako zbiory przykładów moralnych zgodnych z nauką Kościoła. Chociaż Biblioteka była w zasadzie przewodnikiem bibliograficznym i metodycznym dla nauczycieli kolegiów, to jednak zawarte w niej wskazania ukształtowały model recepcji antyku w kulturze całej katolickiej Europy.

\section{NOWOEACIŃSKA POETYKA I CHRZEŚCIJAŃSKI HORACY}

Chrześcijańska reinterpretacja antyku oraz żywe oddziaływanie nowych barokowych prądów w literaturze zaowocowały w XVII wieku powstaniem w Polsce wielu traktatów z zakresu poetyki (ogółem ok. 50 pozycji) ${ }^{24}$. Ogromna ich większość pozostaje jednak do dzisiaj w rękopisach, a jednym z nielicznych dzieł, jakie ukazały się drukiem, była rozprawa pijara Andrzeja Krzyżkiewicza Attica Musa..., wydana w Krakowie w 1674 roku.

Europejskim zapleczem staropolskiej poetyki epoki baroku okazał się głównie neoarystotelizm, który poznawano dzięki dziełom Francesco Robortella, Johana Isaaksza Pontanusa, a zwłaszcza Juliusza Cezara Scaligera. Skonwencjonalizowana i uproszczoną wersję neoarystotelizmu reprezentuje bardzo wiele rękopiśmiennych poetyk szkolnych tych czasów ${ }^{25}$.

$Z$ tych racji wyjątkową pozycję w dziejach polskiej myśli o poezji zajmują teoretycznoliterackie rozprawy Macieja Kazimierza Sarbiewskiego TJ (1595-1640) ${ }^{26}$. Urodzony na Mazowszu, edukację szkolną rozpoczął w kolegium w Pułtusku nad Narwią. Pięć lat później wstąpił do nowicjatu Towarzystwa Jezusowego w Wilnie. Po kursie filozofii w Collegium Hosianum w Braniewie objął stanowisko magistra poetyki i syntaksy w Krożach na Żmudzi, a w latach 1619-1620 prowadził zajęcia $z$ retoryki w kresowym Połocku. Dopełniając kurs teologii przepisany przez Ratio studiorum, w latach 1620-1622 studiował w Akademii Wileńskiej, skąd władze zakonne wystały go do Rzymu.

Owszem, Index expurgatorius librorum (Indeks czyszczacy ksiegi) podawał wykaz fragmentów, które w książkach zasadniczo dozwolonych powinny być jednak usuwane.

24 Zob. T. Sinko, Literatura polsko-łacińska. Problemy i zadania, „Eos” XLV (1951), fasc. 2, s. 1-11.

25 Były to najczęściej skrypty łacińskich wykładów prowadzonych w kolegiach jezuickich bądź pijarskich, stąa w większości pozostały anonimowe.

26 Zob. S. ZABŁocki, Poezja polsko-tacinska wczesnego renesansu. Wybrane zagadnienia, w: Problemy literatury staropolskiej, seria 2, red. T. Pelc, Wrocław 1973, s. 7-102; tenże, Literatura nowołacinska. Średniowiecze - renesans - barok, Warszawa 2010, s. 313-382. 
W Collegium Romanum ukończył IV rok teologii, a następnie w rzymskim Collegium Germanicum pełnił obowiązki prefekta studiów. W okresie rzymskim (1623-1625) poeta zetknął się z wielkimi tego świata - papieżem Urbanem VIII, jego synowcem kardynałem Francesco Barberinim i księciem Paolo Giordano Orsinim. Po powrocie do kraju wykładał Sarbiewski w kolegium w Połocku, a następnie w Akademii Wileńskiej, której profesorem był w latach 1628-1635. Powołany stąd na urząd kaznodziei królewskiego przy boku Władysława IV, ostatnie pięć lat życia spędził na warszawskim dworze.

Najbardziej oryginalnym dziełem Sarbiewskiego z zakresu poetyki był traktat De acuto et arguto, sive Seneca et Martialis (O puencie i dowcipie, czyli Seneka i Marcjalis, 1623), będący pokłosiem jego połockich i rzymskich wykładów. Autor zarysował w nich teorię konceptu, według której istotę poezji stanowi puenta (acutum), prowadząca do zdziwienia i niespodzianki, będących głównymi źródłami przeżycia estetycznego. Tak rozumiana puenta polegała według niego na uchwyceniu wzajemnego związku elementów sprzecznych (concordia discors) lub przeciwnie - ukazaniu sprzeczności tkwiących w pozornej zgodności (discordia concors). Zadaniem twórcy było odkrycie dysharmonii i dziwności skrytych w rzeczach (res) i wyrażenie ich za pomocą środków językowych (verba ${ }^{27}$.

Najobszerniejszym dziełem Sarbiewskiego był traktat o epopei De perfecta poesi, sive Vergilius et Homerus (O poezji doskonalej, czyli Wergiliusz i Homer, 1627). $W$ interesujący sposób połączyt w nim postulaty zawarte w Poetyce Scaligera ze wskazówkami wybitniejszego teoretyka poezji jezuickiej - Johana Pontanusa. Tematem naczelnym poezji uczynił „rzeczy ludzkie”, lecz umieścił je w perspektywie boskiego aktu stworzenia. „Poeta wpisany w universum boskich praw natury miał nie tylko respektować ich istnienie, lecz także wykorzystywać je we własnych dziełach, jako suwerenny twórca-kreator (artifex doctus)" ${ }^{\prime 28}$.

Traktaty Sarbiewskiego, choć nie opublikowane za życia autora, krążyły jednak w licznych odpisach. Ślady ich oddziaływania odnajdujemy w całej Europie, od Hiszpanii po Rosję. Jego teoria puenty wyraźnie wpłynęła na poglądy Baltazara Graciana - najwybitniejszego teoretyka barokowego konceptyzmu.

Horatius Christianus Sarbievius, bo tak brzmiała zlatynizowana forma jego nazwiska, był jednak przede wszystkim poetą łacińskim - być może najwybitniejszym w dziejach polskiej latynistyki. „Sarbiewski doprowadził mającą długą tradycję poezjęłacińską w Polsce do perfekcji - pisał Czesław Miłosz - i aż do dziś żaden polski poeta nie zyskał takiej sławy za granica, jak Sarbiewski za życia i w okresie paru dziesięcioleci bezpośrednio po śmierci"29.

27 Zob. K. Stawecka, Maciej Kazimierz Sarbiewski - prozaik i poeta, Lublin 1989, s. 64.

28 Z. Grochal, Chrześcijański Horacy - Maciej Kazimierz Sarbiewski [1595-1640] TJ i jego estetyka, Niepokalanów 1994, s. 117.

29 Historia literatury polskiej do roku 1939, Kraków 1993, s. 147. 
Uwieńczony w 1625 roku przez papieża Urbana VIII laurem kapitolińskim, już przez współczesnych okrzyknięty został „chrześcijańskim Horacym” (Horatius Christianus). Jego Lyriconum libri (Ksiegi liryków), wydane po raz pierwszy w Kolonii w 1625 roku, miały około 60 wznowień, z czego na Polskę przypada tylko 15. Poeta wzniecił w nich barokową wizję chrześcijańskiego horacjanizmu, w którym na plan pierwszy wysuwały się fundamentalne pytania dotyczące sensu ludzkiej egzystencji. Tworzyły one metafizyczną ramę, w której umieszczał panegiryczne pochwały Urbana VIII, cesarza Ferdynanda II czy kardynała Francesco Barberiniego, strofy kierowane do przyjaciół, wreszcie tematy współczesne. Ich poetyckimi wcieleniami były zaś parodie i palinodie horacjańskie.

Termin „parodia” nie miał w staropolszczyźnie ośmieszającego lub przedrzeźniającego charakteru. Była to technika polegająca na tworzeniu nowołacińskich poezji $\mathrm{z}$ wykorzystaniem elementów struktury utworów antycznych. Jej całościową realizacją jest pieśń 11,26 Sarbiewskiego Ad D. Virginem Matrem (Do Dziewiczej Matki Boga). Poeta wykorzystał w niej do stworzenia wiersza maryjnego materię pieśni I, 30 Horacego O Venus regina Cnidi ( $O$ Wenus królowo Knidos), będącej erotykiem stylizowanym na hymn.

Palinodia horacjańska była z kolei rodzajem ideowego dialogu, prowadzonego przez chrześcijańskiego poetę z parafrazowanym przez siebie utworem pogańskiego wieszcza. Tak było w epodzie III Laus otii religiosi (Pochwała spokoju w zakonie), gdzie Sarbiewski zanegował sielskie przesłanie epody II Horacego Beatus ille qui procul negotiis... (Szczęśliwy ów, kto z dala od zajęć):

Lecz dziś, Horacy, ten będzie szczęśliwszy,

Kto trosk i trudów żywota się zbywszy,

Ojcowskiej wioski porzucając pola,

Z jarzma świeckiego uwolnić się zdoła

(tłum. A.W. Mikołajczak ${ }^{30}$ ).

Podziwiano i naśladowano Sarbiewskiego w całej Europie. „Uni cedis Horatio ustępujesz tylko Horacemu", pisał Gilbertus Ioninus ${ }^{31}$. Mortierus uważał, że równy jest Horacemu (Horatio par). Natomiast wielki humanista holenderski Hugo Grotius powiedział o nim wręcz: ,non solum aequavit, sed interdum superavit Flaccum - nie tylko dorównał Horacemu, lecz jeszcze go przewyższył" "2.

Nigdzie jednak Sarbiewski nie cieszył się większą estymą niż w Anglii. Pierwszy tom angielskich przekładów jego dzieł, zatytułowany Odes of Casimire, ukazał się

Eacina w kulturze polskiej, Wrocław 2005, s. 85.

Selecta poetica auctorum latinonum, Poetae Veteres, Friburgi Helvetorum 1830, s. 398.

32 E. Buszewicz, Sarmacki Horacy i jego liryka: imitacja, gatunek, styl: rzecz o poezji Macieja Kazimierza

Sarbiewskiego, Kraków 2006, s. 75. 
już w 1646 roku. Dobrze znał jego poezje i wiele z niej zaczerpnął Henry Vaughan, czołowy przedstawiciel angielskich poetów metafizycznych. Także Samuel Taylor Coleridge jako młody człowiek chciał tłumaczyć ody Casimira. Mawiał, że z wyjątkiem Lukrecjusza i Stacjusza nie zna żadnego poety łacińskiego, o którym można by powiedzieć, że dorównuje Casimirowi śmiałością koncepcji, bogactwem wyobraźni czy pięknem wersyfikacji.

Niestety, po śmierci Sarbiewskiego żaden z polsko-łacińskich poetów nie osiagnął już podobnej miary talentu. Niemniej pozostawił on w Polsce kilku naśladowców. Wśród nich wyróżniali się: Albert Ines (1620-1658), nazywany „wieszczem Maryjnym" (vates Marianus), autor złożonego w strofach safickich Horologium Marianum (Godzinki Maryjne, 1643), oraz Jędrzej Kanon (1612-1685), który w Lyricorum libri IV (Liryków ksiag IV, 1643) opiewał stulecie Towarzystwa Jezusowego.

\section{IMPERIUM LATINITATIS I UTRATA POZYCJI EACINY}

Fenomen łacińskojęzyczności mieszkańców Rzeczypospolitej zdumiewał obcych. Ulrich von Werdum wspomina w swym pamiętniku z podróży do Polski, że we Lwowie jakaś mieszczka, rozpoznawszy w nim cudzoziemca, odezwała się do niego klasyczną łaciną ${ }^{33}$. Znana była też anegdota o cesarzu Ferdynandzie II, który po łacinie rozmówił się z woźnicą arcybiskupa gnieźnieńskiego. W Europie tworzyła się legenda kraju, w którym każdy, począwszy od króla, a skończywszy na służebnym pachoł$\mathrm{ku}$, posługuje się językiem Cycerona.

W istocie łacina w Polsce rozbrzmiewała prawie wszędzie - na dworze królewskim i na dworach magnackich, w jezuickim kolegium ina konwiktowej scenie, w kościele, na sejmikach i na sejmie, nie mówiąc już o palestrze i spotkaniach z cudzoziemcami. Szlachta demonstrowała w ten sposób przynależność do łacińskiej cywilizacji, wierność wobec rzymskokatolickiej wiary, wreszcie swą pozycję społeczną.

Konsekwencją powszechnego używania łaciny tak w mowie, jak i w piśmie była praktyka makaronizowania, czyli inkrustowania polszczyzny łacińskimi wyrażeniami i zwrotami. Nie można jej traktować jako plagi językowej ani bełkotu przypominającego mowę Salvatora z Imienia róży Umberto Eco, jest to bowiem fascynujący socjodialekt ówczesnych elit społecznych Rzeczypospolitej. „Około czego publicis questionibus poruszony - pisał w 1646 roku w liście do Władysława IV Stanisław Lubomirski dyssymulować mi się więcej nie godzi, w czym fides mea i ojczyzny całość vertitur" ${ }^{34}$.

33 Zob. U. Werdum, Dziennik podróży 1670-1672. Dziennik wyprawy polowej 1671, wstęp i oprac. D. Milewski, Warszawa 2012.

34 Publicis questionibus - publicznymi zagadnieniami; fides mea-moje zobowiązania; vertitur-wchodzi w grę (tłum. własne), cyt. za: Między Slavia Latina i Slavia Orthodoxa, red. E.J. Głębicka, Warszawa 1995, s. 65. 
Claude Backvis (1910-1998) nazwał tę mowę „trzecim językiem Polaków”35, zwracając uwagę na autonomiczną wartość semantyczną konstruowanych $w$ ten sposób wypowiedzi. W istocie tłumaczenie owych łacińskich inkluzji nie tylko zabija ekspresję, ale i gubi sens makaronicznego tekstu.

Oprócz pisanych w tej manierze dokumentów, listów, mów, traktatów w czasach baroku rozwinęła się także żartobliwa poezja makaroniczna. Kierunek ten, świetnie zapoczątkowany w dobie renesansu przez Piotra Roizjusza i Jana Kochanowskiego, w XVII wieku zyskał jeszcze na znaczeniu. Za najlepsze i najobszerniejsze dzieło barokowego makaronizmu uchodzi zbiór Stanisława Orzelskiego Macaronica carmina Marfordii Mądzikovii poetae approbati (1623).

Ucieszne carmina macaronica należały do ulubionych rozrywek w kręgu kultury szlacheckiej. Człowiek polskiego baroku to przecież „człek bawiący się” - homo ludens, który rad wprzęgał łacinę w dystrakcję, grę i żart literacki. Skorzystała na tym także poezja kunsztowna (poesis artificiosa), uważana za wyrafinowaną zabawę gramatyczną, metryczną i figuralno-geometryczną. Nurt ten wydał licznych poetów, którzy w okresie późnego baroku masowo tworzyli tego rodzaju dziełka, więcej zawdzięczające przemyślności niż prawdziwemu talentowi piszących. Przykładem może być Piotr Pogorzelski, który w 1639 roku opublikował zbiór takich właśnie kunsztownych drobiazgów zatytułowany Adorea feriarum (Chwała świą).

Do starej, średniowiecznej tradycji łacińskich wierszy-cacek, wierszy-zabawek, cieszących zarówno ucho, jak i oko czytelników, nawiązywały utwory figuralne (carmina figurata). Lubował się w nich Klemens Stanisław Herka, autor Liber passus (Ksiega tropów) z 1732 roku, piszący wiersze w kształcie kół, obelisków lub gwiazd. Mistrzem anagramatów - wierszyków tworzonych z przestawienia liter wyrazów był natomiast Bartłomiej Kazimierz Malicki, autor Centuria anagrammatico-epigrammatica (Centuria anagramatyczno-epigramatyczna, 1688).

Do poezji kunsztownej, lecz o poważnym moralizatorskim tonie, należały także Adverbiorum moralium (...) libellus (Przystówki moralne, 1688) Stanisława Herakliusza Lubomirskiego (1641/42-1702). Sztuczki językowe rodem z wierszy-zabawek, polegające między innymi na obsesyjnym powtarzaniu przysłówków: semper (zawsze), ad (do), cum (z) itp., autor połączył tu z głębokimi refleksjami o charakterze metafizycznym ${ }^{36}$.

Mimo niewątpliwych osiagnięć poszczególnych pisarzy łacina, będąca w XV wieku jedynym uznanym językiem międzynarodowej nauki i literatury pięknej, w XVI wieku traci uprzywilejowaną pozycję, najpierw we Włoszech, gdzie pojawiają się utalentowani pisarze narodowi, później we Francji i Anglii, a w XVII wieku w Niemczech. Od tego też czasu literatura nowołacińska zaczyna powoli ustępować znaczeniem

35 C. Backvis, Panorama de la poésie polonaise à l'âge baroque, Bruxelles 1995, s. 221.

36 Zob. S. JASIŃsKa, Stanisława Herakliusza Lubomirskiego „Myśli o wieczności”, „Pamiętnik Biblioteki Kórnickiej" 1968, z. 9-10, s. 48. 
i popularnością piśmiennictwu w językach rodzimych. I choć szkoła jezuicka znacznie wzmocniła prestiż łaciny i studiów klasycznych, nie potrafiła jednak zahamować procesu emancypacji języków narodowych, zwłaszcza w XVII wieku języka francuskiego, który powoli wypiera łacinę jako język literatury, nauki i wreszcie dyplomacji ${ }^{37}$.

\section{5. ŁACINA JAKO JĘZYK NAUKI I PRZEKEADU}

Tezy Charles'a Perraulta (1628-1703) wyraźnie uwidoczniły fakt, że w ciągu wieku XVII łacina traciła znaczenie jako język artystyczny. Mimo to długo jeszcze pozostała językiem nauki i międzynarodowego porozumienia. Większość dzieł naukowych w XVI i XVII wieku ukazała się po łacinie, z Philosophiae naturalis principia mathematica Izaaka Newtona na czele (1687). Używali jej: biolog Karol Linneusz, lekarz William Harvey, odkrywca tajników krwiobiegu, anatom Andreas Vesalius, astronom Tycho de Brahe, filozofowie: Francis Bacon, René Descartes, Pierre Gassendi, Thomas Hobbes i znakomity latynista Baruch Spinoza. Większość dzieł medycznych, chemicznych czy fizycznych ukazywała się jeszcze w XVII wieku, nie mówiąc już o poprzednich stuleciach, po łacinie lub też w przekładzie łacińskim, który zapewniał im uwagę międzynarodowych czytelników.

To samo powiedzieć można o piśmiennictwie popularnym: łaciński przekład spopularyzował twórczość alchemika Paracelsusa czy przepowiednie Nostradamusa. Podobnie moda na filozofię i kulturę orientalną zaczęła się od łacińskich parafraz dzieł myślicieli wschodnich, na przykład jezuity Ignatia de Costa Sapientia Sinica. Międzynarodową popularność zyskiwały dzieła literackie stworzone w językach narodowych także poprzez tłumaczenia na łacinę, dopiero później tę rolę zaczął odgrywać język francuski. Zwyczaj tłumaczenia z języków narodowych na łacinę dzieł nie tylko naukowych czy filozoficznych, ale także literackich wywodził się jeszcze z czasów odrodzenia dwunastowiecznego: jednym z pierwszych przełożonych na nią poematów był Roman de Troie Benoît de Sainte-More z XII wieku, sparafrazowany w prozaicznym dziele Guidona delle Colonne (1210-1287) pt. Historia Troiana. W podobny sposób w czasach renesansu parafrazowano Boską komedię Dantego, nie wspominając już o renesansowych przekładach Sebastiana Branta ${ }^{38}$.

\footnotetext{
37 Wyrazem tych zmian stał się spór wywołany przez Charles’a Perraulta (1628-1703), który w sławnym porównaniu starożytnych z nowożytnymi (Paralleles des anciens et des modemes, 1688) jakby podsumował dorobek współczesnej mu kultury (przede wszystkim francuskiej), stwierdzając, że ma ona równie wielkie osiągnięcia co kultura antyczna. Pośrednio zaś wystąpił Perrault przeciw uprawianiu twórczości w języku starożytnych na niekorzyść francuskiego, który w XVII wieku równie dobrze jak łacina klasyczna potrafił wyrazić problemy i uczucia człowieka nowożytnego.

38 Zob. Humanitas - projekty antropologii humanistycznej, cz. 1: Paradygmatj, tradycje, profile historyczne, red. A. Nowicka-Jeżowa, Warszawa 2010, s. 213.
} 
Największą poczytność zdobyły sobie nowele Dekameronu Boccaccia, przekładane przez różnych pisarzy na łacinę prozą i wierszem. Poczet ich otwiera Petrarka, który przetłumaczył Opowieść o cnotliwej Gryzeldzie (X, 10), z kolei często parafrazowaną w językach narodowych, także po polsku: opowiadanie to należało też do ulubionych dzieł piśmiennictwa ludowego w XVI i XVII wieku. Do Polski dotarły zresztą za pośrednictwem łaciny również $\mathrm{i}$ inne nowele z Dekameronu i najlepiej ilustrują one ogromną popularność łacińskich wersji dzieła włoskiego humanisty.

Za pośrednictwem łacińskich przekładów i parafraz zapoznawano się też z arcydziełami literatury włoskiej: Jerozolima wyzwolona Torquata Tassa (Londyn 1584, Wenecja 1585, Vicenza 1623), Dworzaninem Baldassare Castiglionego, przełożonym na łacinę w 1571 roku, czy ze sławnym podręcznikiem ówczesnego savoir-vivre’u, traktatem Giovanniego Della Casa Il Galateo, wydanym w 1559, a zlatynizowanym w 1595 roku. Przeciwieństwem jakby przekładów literatury dworskiej była łacińska wersja popularnej książki niemieckiej Till Eulenspiegel (1515), najwybitniejszego dzieła piśmiennictwa sowizdrzalskiego. Doczekało się ono aż dwóch przekładów na łacinę, jako Triumf głupoty ludzkiej (Triumphus humanae stultitiae, 1558) oraz Sowie zwierciadto (Noctuae speculum, 1567). Tłumaczenia te w niemałym stopniu przyczyniły się do popularności dziełka i wyrastającego $z$ niego piśmiennictwa sowizdrzalskiego XVII stulecia.

W XVII wieku za pomocą przekładów łacińskich zapoznawano się głównie z dziełami znakomitych autorów pisujących w rzadziej wówczas znanych językach: angielskim czy portugalskim, a nawet hiszpańskim, podczas gdy twórczość Włochów w mniejszym stopniu wymagała tej formy popularyzacji. W roku 1624 ukazał się więc pod charakterystycznym barokowym tytułem Pornoboscodidascalus latinus przekład Kaspra Bartha Celesryny (1499) dramatu przypisywanego Fernandowi de Rojas (1465-1541) - najwybitniejszego, obok Don Kichota Cervantesa, dzieła literatury starohiszpańskiej, tłumaczonego zresztą już od wieku XVI na wiele języków europejskich. Jeszcze bardziej wymowne są przekłady Luzjady Luiza de Cambesa (oryginał ukazał się w 1572 roku, przekład łaciński w 1622) czy Raju utraconego Johna Miltona (oryginał 1667, parafraza łacińska 1702). Jeszcze w XVIII wieku wszystkie wybitniejsze dzieła angielskich poetów tej epoki: Johna Drydena, Alexandra Pope'a i Thomasa Graya, w niewiele lat po ukazaniu się oryginału udostępniano w łacińskich przekładach międzynarodowej publiczności literackiej.

W XVIII wieku ukazał się łaciński przekład Bajek La Fontaine’a (oryginał wydany w 1668, przekład łaciński w wyborze 1749 i 1765) oraz Henriady Voltaire'a, dzieł uznawanych za reprezentatywne utwory francuskiego klasycyzmu. Przekłady z języka francuskiego na łacinę należały już wówczas do wyjątków z uwagi na powszechną niemal znajomość tego pierwszego w XVIIl wieku, wtedy bowiem właśnie francuski zastępuje łacinę w jej funkcji języka literatury międzynarodowej, przekazującej nowe myśli i idee artystyczne. Jak w XVI i XVII stuleciu autorzy różnych 
narodowości tworzyli po łacinie, tak w wieku oświecenia pisano w języku Voltaire'a. Fryderyk Wielki uważał przecież, że wiersze tworzyć można jedynie po francusku, w tym języku Stanisław August pisał swe pamiętniki, jakby usprawiedliwiając się przed Francuzami z winy za rozbiory Polski, Jan Potocki zaś - swe znakomite utwory dramatyczne i powieści.

Renesansowe i barokowe przekłady na łacinę nie były jedynie domeną poezji i prozy świeckiej. Z tego samego narzędzia popularyzacji korzystał Kościół. Szczególnie popularne stały się przekłady literatury mistycznej, sięgającej swoimi korzeniami jeszcze do średniowiecza. Tłumaczono mistyków nadreńskich, piszących w oryginale w starych dialektach flamandzkich, czy pisma najwspanialszych przedstawicieli złotego wieku mistyki hiszpańskiej: św. Teresy od Jezusa i św Jana od Krzyża. Na polu pracy z teksami Doktora Mistycznego wsławił się polski karmelita bosy -świetnie wykształcony, prawdziwy syn swoich czasów, Andrzej Brzechwa herbu Jastrzębiec.

\section{ANdRzej BRZECHWa - mistycZna POEZJA I PROZA W JĘZYKu HORACEGO}

Jedyne źródła historyczne na temat Andrzeja Brzechwy to informacje w łacinskich zakonnych nekrologach, które jako ostatni solidnie uporządkował Czesław Falkowski (1887-1969), przygotowując materiały do Polskiego słownika biograficznego. Głównym ich źródłem pozostaje pierwszy nekrolog sporządzony przez Ignacego od św. Jana, powtarzany lub kontaminowany później w zbiorowych opracowaniach takich jak Decore Carmeli Religiosi, Historia Generali Carmelitanorum Excalceatorum Congregationis Italicae czy Bibliotheca Carmelitana ${ }^{39}$.

Andrzej Brzechwa (Brzechffa) herbu Jastrzębiec urodził sięw Brzesku (w transkrypcji łacińskiej Brizosth). Jan Brzechwa (uczestnik walk pod Pskowem) i Zofia z Jarzynów ochrzcili syna 28 maja 1584 roku imieniem jego krewnego Andrzeja, opata tynieckiego ${ }^{40}$. Brzechwa uczył się na początku w domu, w piętnastym roku życia wyjechał do Rzymu w orszaku kardynała Jerzego Radziwiłła, biskupa krakowskiego, który latem 1599 roku wyruszał na wielki jubileusz. Przeszło dwa lata studiował

39 Zob. Brzechwa Andrzej, w: Polski stownik biograficzny, t. III, Kraków 1937, s. 32-33; STeKerTowie, Stownik biograficzno-historyczny Polski, Kraków 1885, s. 253; Philippus a SS. Trinitate, Decor Carmeli religiosi, Lugduni 1665; F. Jaroszewicz, Matka Świętych Polska, Kraków 1767, s. 213-235; „Pamiętnik religijno-moralny” 1842, t. II, s. 515-516; K MEChERzYŃSKi, Historia wymowy w Polsce, t. II, Kraków 1858, s. 449; „Głos Karmelu” 1933, nr 5, s. 166; Analecta Ordinis Carmelitanum Discalceatorum, Romae 1933, vol. VIII, fasc. II, s. 194-196.

40 Andrzej Brzechwa (zm. 1593), opat klasztoru benedyktynów w Tyńcu. Studia wyższe odbył na Uniwersytecie Krakowskim (bakałarz sztuk wyzwolonych). Po wstąpieniu do zakonu w niedługim czasie został przeorem klasztoru, potem prepozytem św. Wawrzyńca w Kościelnej Wsi pod Kaliszem, wreszcie w 1572 roku opatem po Hieronimie Krzyżanowskim. Ze względu na trudny charakter i lekkie obyczaje w 1582 roku popadł w konflikt $\mathrm{z}$ biskupem krakowskim Piotrem Myszkowskim. Zmarł 4 lutego 1593 roku. 
retorykę i filozofię w Collegium Romanum. Przypadkiem w kościele Santa Maria della Scala usłyszał kazanie wybitnego karmelity bosego Jana od Jezusa i Maryi i postanowił, wbrew woli ojca, wstąpić do świeżo zreformowanego Karmelu. Niezadowolony ojciec napisał w tej sprawie do Klemensa VIII i kardynała protektora zakonu. Po zbadaniu powołania na rozkaz papieski przez wielkiego kardynała Baroniusza pozwolono Brzechwie pozostać w zakonie. Przy obłóczynach (15 października 1602) otrzymał imię Bruno. Pod wpływem ojca władze zakonu zachowały jednak jego imię chrzcielne i 11 listopada 1603 roku złożył profesję zakonną jako Jędrzej od Jezusa.

Studia teologiczne odbył w Genui, gdzie otrzymał święcenia kapłańskie (14 marca 1609) i wrócił do Polski. Już w 1610 roku wydał w Krakowie u Piotrkowczyka żywot świętobliwie zmarłego w 1608 roku Marcina Jażewicza pt. Krótkie opisanie żywota i cnót wielebnego brata Aleksego a Sancto Bernardo, Polaka Lubelczyka, karmelity bosego. Stał się wybitnym kaznodzieją i organizatorem budowy nowych klasztorów w Krakowie, Lublinie i Lwowie. Z powodu napięć pomiędzy ówczesnymi mistrzami ambony został przeniesiony za granicę ${ }^{41}$. W Kolonii z powodzeniem głosił kazania po włosku i po łacinie, w 1615 roku był wizytatorem benedyktyńskiego opactwa św. Korneliusza, skąd powołano go do Antwerpii, gdzie głosił po hiszpańsku kazania wielkopostne. Był spowiednikiem bł. Anny od św. Bartłomieja. W Brukseli poznał drugą towarzyszkę wielkiej Teresy, Annę od Jezusa.

W 1628 roku wrócił do kraju, przywożąc ze sobą wiele relikwii, które złożył w Lublinie. Wybrany definitorem, dalej niestrudzenie pracował na ambonie i przy zakładaniu kolejnych klasztorów w Poznaniu, Przemyślu i Czernej. W 1628 roku Kongregacja Propagandy na prośbę metropolity kijowskiego, Józefa Welamina Rutskiego, poleciła mu pracę nad reformą zakonu bazyliańskiego w Polsce. Nie podjął się jednak tego zadania ze względu na zły stan zdrowia. W tym czasie zaczął przekładać z hiszpańskiego na łacinę dzieła św. Jana od Krzyża, k tóre po raz pierwszy wydano w Kolonii w 1639 roku. Zmarł w Lublinie 19 lub 29 kwietnia 1640 roku, pozostawiając w rękopisach trzy dzieła o treści ascetycznej.

Pisma św. Jana ukazały się po raz pierwszy w Alcalá w 1618 roku. Pierwsi przełożyli je na łacinę Francuzi w 1622 roku i Włosi w 1627 roku. Trzecim przekładem była praca Andrzeja Brzechwy (wydana w 1639 roku w Kolonii), który w ten sposób udostępnił dzieła Doktora Mistycznego Europie Środkowej i Wschodniej, silnie jeszcze zakotwiczonej w kulturze łacińskiej, jak zaznacza we wstępie sam tłumacz ${ }^{42}$. Łacińską wersję dzieł św. Teresy wydano w Moguncji w 1608 roku, zatem drugi wielki reformator Karmelu czekał na popularyzację ponad 30 lat. Wydanie łacińskie z 1639

41 Subtelnie wspomina o tym Bibliotheca Camnelitana, t. I, s. 83: „Universalis applausus, aemulos ipsi paravit; a quibus multa passus, persecutioni cedens - Powszechnie szanowany, nabawił się konkurentów, przez których wiele cierpiał, doświadczając prześladowania" (tłum. własne).

42 ,...novissimam interpretationem latinam, quae pluribus nationibus est communior..."; Opera Mystica Venerabili ac Mystici Doctoris F. Joannis a Cruce..., Coloniae 1639, wstęp, s. 7. 
roku jest imponujące. To mały egzemplarz w sztywnej skórze, liczący ponad 500 grubych stron zadrukowanych małą czcionką. We wstępie tłumacz usprawiedliwia się na wypadek niezrozumiałych fragmentów: pisze, że „to materia trudna dla umysłu i niełatwa do oddania również w innym języku, jednak lepiej mieć jakikolwiek przekład, niż nie mieć go wcale"43.

Ponieważ św. Jan od Krzyża cytował Biblię wprost z Wulgaty, wykorzystując czasami zależność rodzącego się wernakularnego hiszpańskiego od łaciny, Brzechwa pod pewnym względem miał ułatwione zadanie - Wulgata niosła ze sobą gotową terminologię. Przykładem może być komentarz do strofy 7 w Pieśni duchowej, gdzie św. Jan wykorzystuje pokrewieństwo hiszpańskiego czasownika vagar z łacińskim vacare, co $\mathrm{w}$ tłumaczeniach na język polski zawsze powodowało nieporozumienia:

A las criaturas racionales, como habemos dicho, entiende aquí por los que vagan, que son los ángeles y los hombres, porque solos éstos de todas las criaturas vagan a Dios entendiendo en él; porque eso quiere decir ese vocabolo vagan, el cual en latin se dice vacant (Cantico Espiritual B 7:644).

Creaturas rationales, prout diximus, vacantium nomine hic intelligit, qui sunt Angeli et homines. Nam isti tantum inter cætera creata Deo vacant, intendentes in eum; id enim significat verbum vacant (tłum. Andrzej Brzechwa OCD ${ }^{45}$ ).

Przez te dzieła, które się przesuwają, jak to już zaznaczyliśmy, pojmuje dusza stworzenia rozumne: ludzi i aniołów, gdyż tylko oni spośród wszystkich stworzeń chodzą przed Bogiem, tj. poznają Go. To chce wyrazić przez słowo „przesuwają się", które w języku łacińskim odpowiada słowu vacant (tłum. Bernard Smyrak OCD ${ }^{46}$ ).

Jak już wspominaliśmy, dusza uważa za stworzenia rozumne te, które wędru$j a$, czyli aniołów i ludzi, ponieważ ze wszystkich stworzeń tylko one wędrują ku Bogu, rozpoznając Go. To właśnie oznacza słowo wędrują. W języku łacińskim mówi się vacant (...) (tłum. Carlos Marrodán Casas ${ }^{47}$ ).

Kiedy św. Jan od Krzyża w komentarzach pisanych prozą nawiązuje do kategorii teologicznych lub filozoficznych, również posługuje się kalkami z łacińskiej

43 "Quamvis enim non sit usquequaque perfecta, et aliquibus in locis obscura videatur locutio, mirum videri non debet, si materia ex se intellectu difficilis, alieno idiomate non adeo clara et perspicua reddatur, praestat nihilominus aliquam interpretationem, licet non ita exactam habere, quam nullam"; tamże.

44 San Juan de la Cruz, Obraz completas, Madrid 1988, s. 608.

45 Opera Mystica Venerabili ac Mystici Doctoris F. Joannis a Cruce..., s. 358.

46 Św. Jan od Krzyża, Dzieła, tłum. B. Smyrak, Kraków 2014, s. 683.

47 Św. Jan od KrzYża, Pieśń duchowa, tłum. C. Marrodán Casas, M. Kurek, Kraków 2017, s. 155. 
nomenklatury scholastycznej $j^{48}$. Przy tak wysokim poziomie zależności oryginału od tekstów łacińskich może dziwié, dlaczego autor od początku nie napisał wszystkiego po łacinie. Kluczem do zrozumienia tej hybrydowej strategii jest jego poezja, która stała się zasadniczym nośnikiem treści. Traktaty mistyczne św. Jana od Krzyża są ostatecznie komentarzem do utworów poetyckich, a ponieważ poezja po renesansowym przewrocie jest osobista i zakotwiczona w realiach czasu i przestrzeni, nie mógł inaczej wyrazić swojego ducha, jak tylko w języku ojczystym, codziennym: w języku modlitwy, rozmów i myślíi ${ }^{49}$.

Rozumiał to również Brzechwa, ponieważ na 350 lat przed naszymi współczesnymi dwujęzycznymi wydaniami cytuje oryginalny tekst poetycki obok własnego literackiego przekładu, na początku każdego rozdziału komentarza dołączając jeszcze przekład studyjny, dosłowny, aby współbrzmiał z tekstem. Najlepszą ilustracją takiego zabiegu będzie pierwsza zwrotka Nocy ciemnej. Brzechwa podaje w kolejności tekst hiszpański, tłumaczenie literackie i tłumaczenie dosłowne:

En una noche e fcura,

Con anjias en amores inflammada,

O dichofa ventura,

Sali Jin Jer notada,

Ejtando ya mi cafa $\int o \int e g a d a^{50}$.

Noctis obfcuræ tenebris, Amoris

Aejtuans flamma, Jtimulifque pulfa

[o bonam fortem nimis et beatam]

Sola prorupi: procul exeuntis

Confcio nullo, Jopor altus omnem

Cum domum tandem placida quiete

Compofuifjet ${ }^{51}$.

Quadam nocte obfcura

Amoribus anxijs inflammata

O sortem fortunatam

Exiui, nec fui obferuata

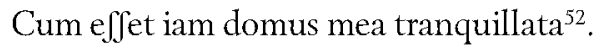

48 Crisógono de Jesús Sacramentado, San Juan de la Cruz. Su obra científicay su obra literaria, t. 2, Avila 1929 , s. 109.

49 Por. E. Orozco Díaz, Poesía y mústica, Madrid 1959, s. 165.

50 Opera Mystica Venerabili ac Mystici Doctoris F. Joannis a Cruce..., s. 191.

51 Tamże, s. 191.

52 Tamże, s. 194. 
Na pierwszy rzut oka widać wyraźnie, że w przypadku tłumaczenia poetyckiego na łacinę Brzechwa pozwolił sobie na wykorzystanie tendencji epoki i - jak przyznaje we wstępie - wtłacza treść utworu w strofę saficką (metro sapphico). W oryginale św. Jan posługuje się tzw. lirą̧ ${ }^{53}$ o której Dámaso Alonso wypowiedział słynne zdanie: „Lira, pogańska strofa Garcilaso, została uduchowiona przez Ludwika z Leónu i ubóstwiona przez św. Jana od Krzyża" ${ }^{54}$. Lira składała się z pięciu wersetów, trzech jedenastozgłoskowych, dwóch siedmiozgłoskowych, $\mathrm{z}$ rytmem męskim o dystrybucji 7a, 11B, 7a, 7b, 11B. Germán Vega García-Luengos uważa, iż taka metryka została wybrana ze względu na fakt, że tekst miał być przede wszystkim śpiewany, zatem łatwiej zapamiętywany i przekazywany dalej ${ }^{j 5}$.

Strofa saficka (mniejsza), którą wykorzystuje Brzechwa, składa się w klasycznym schemacie z trzykrotnie powtórzonego jedenastozgłoskowca (versus hendecasyllabus Sapphicus) i adoniusa. Pojawia się ona u liryków eolskich. W poezji rzymskiej użył jej po raz pierwszy Katullus. Budowę jedenastozgłoskowca znormalizował Horacy, na którego tak często powoływali się nowołacińscy twórcy i tłumacze. Czwarta zgłoska tego wiersza jest u niego zawsze długa, a poza tym wiersz ma zawsze cezurę; przypada ona w zasadzie po zgłosce piątej, jak w Carmina I 2, 1-4:

Iam satis terris $\|$ nivis atque dirae grandinis misit | pater et rubente dextera sacras $\|$ iaculatus arces terruit urbem

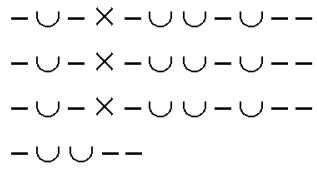

Widać teraz wyraźnie, że Brzechwa podwoił liczbę wierszy do sześciu jedenastozgłoskowców i zakończył klasycznie adoniusem, czyli klauzulą złożoną z daktyla i trocheja, pierwotnie wykorzystywaną do pochwały Adonisa, co podkreśla symbolicznie miłosny i mistyczny charakter Nocy ciemnej.

Brzechwa nie zawsze trzyma się wiernie oryginału, albo przynajmniej takiego oryginału, jaki my znamy. Żywy płomień mitości czy Pieśn duchowa zachowały się w dwóch redakcjach, być może nieautoryzowanych odpisów było jeszcze więcej. Na podstawie

53 Por. E. Orozco Díaz, Estudios sobre San Juan de la Cnuz y la mística del barroco, t. 1, Granada 1994, s. $69-70$.

54 La poesía de San Juan de la Cruz (desde esta ladera), Madrid 1966, s. 25-26.

55 Por. Germán Vega García-Luengos, La poesia de San Juan de la Cruz. Fuego de palabras, „Revista de Espiritualidad" 1991, nr 49, s. 398-399. 
samego przekładu Brzechwy nie jesteśmy w stanie określić, z jakiego tekstu korzystał. Chociaż tłumaczy 40 strof Pieśni duchowej, a liczba ta jest charakterystyczna dla kodeksu B, w treści kontaminuje dostępne mu wersje. Oczywiście, jako nowołaciński tłumacz nie jest niewolnikiem tekstu oryginalnego, zachowuje właściwości zdania i frazeologii łaciny klasycznej, takie jak pozycja czasownika, użycie konstrukcji ablativus absolutus czy accusativus cum infinitivo, modalne partykuły czy rozbudowa lub redukcja zdań. Nie jest jednak w tych zabiegach konsekwentny, co niekiedy zaciemnia rozumienie tekstu, jak w tym fragmencie z $\dot{Z} y w e g o$ ptomienia miłości:

Para encarecer el alma el sentimiento y aprecio con que habla en estas cuatro canciones, pone en todas ellas estos términos: oh! Y cuán, que significan encarecimiento afectuoso. Los cuales, cada vez que se dicen, dan a entender del interior más de lo que se dice por la lengua (Llama de amor viva $\mathrm{B}, 1: 2^{56}$ ).

Aby podkreślić [dosł. uczynić droższym] uczucie i wartość, z jakimi dusza mówi w tych czterech strofach, stawia w każdej z nich wyraz och i jak, które oznaczają uczuciową przesadę. One, za każdym razem, kiedy się je wypowiada, pozwalaja rozumieć głębiej niż to, co się wypowiada językiem (tłum. własne).

Ut sensum et æstimationem, cum qua in istis quatuor cantibus loquitur anima, graphice exprimat, in omnibus illis dictionibus O et Quam, utitur, quibus affectu plenam exaggerationem significat, quæ quotiescunque proferuntur, multo amplius de interioribus innuunt rebus, quam verbis explicetur (tłum. Andrzej Brzechwa $\mathrm{OCD}^{57}$ ).

Przytoczony fragment przedstawia kilka ciekawych cech obranej przez Brzechwę strategii przekładu. Tłumacz nie śledzi wiernie składni zdania hiszpańskiego ani nie stara się o zachowanie dosłowności (ad verbum). Chce, aby czytelnik lepiej zrozumiał tekst, zawężając wieloznaczne czasowniki, np. wieloznaczne hiszpańkie encarecer (dosł. podrażać) przełożył za pomocą łacińskiego wyrażenia graphice exprimare (dokładnie wyrażać). Tłumaczy niektóre człony za pomocą peryfrazy, np. encarecimiento afectuoso zostało oddane przez affectu plena exaggeratio. Czasami natomiast pomaga rozumieć tekst św. Jana samym native speakerom, zawężając w tłumaczeniu starohiszpańskie lengua (język) do łacińskich verba (słowa) ${ }^{58}$.

San Juan de la Cruz, Obraz completas, s. 775.

Opera Mystica Venerabili ac Mystici Doctoris F. Joannis a Cruce..., s. 278.

58 Por. V. García de la Concha, Filología y mística de San Juan de la Cruz, "Llama de amor viva". Discurso en su recepción pública a la Real Academia Española, Madrid 1992, s. 28. 


\section{Karmelitańsika latinitas}

Zdanie po zdaniu przekład Brzechwy jest kopalnią wiedzy o czasach i kulturze, do których nie mamy już łatwego dostępu. Łacińskie tłumaczenia dzieł renesansowych twórców są niezwykle cenne, ponieważ wskazują, jak bardzo zmieniły się pola semantyczne powszechnie używanych słów. Ten mechanizm dotyczy również języka polskiego, w którym na przykład „opona” oznacza dzisiaj prawie wyłącznie gumową ochronę dętki, w czasach Kochanowskiego natomiast była to ozdobna tkanina. Ile nieporozumień zatem może nieść brak znajomości historycznej etymologii słów, których używamy na co dzień: „Tę [Helenę] w jej domu nalazła! A ona wiązała oponę, w której bitwy obie wyrażała trojańskiego rycerstwa z Greki walecznemi!"59.

Twórczość zapomnianego Andrzeja Brzechwy stanowi obszerny materiał do badań nad językiem i kulturą nowołacińską w Polsce i w Europie. Łacina jako lingua franca przetrwała pożogę reformacji i kontestację twórców nowożytnych. Dzisiaj jest wspaniałym przykładem kanału komunikacyjnego, dzięki któremu możemy lepiej rozumieć początki wernakularnych języków Europy. Łaciński przekład dzieł św. Jana od Krzyża pozwala nam konsultować współczesne przykłady w spornych miejscach i odkrywać nowe poziomy mistycznego języka reformatora i mistrza Karmelu.

\section{WYBRANA BIBLIOGRAFIA}

Analecta Ordinis Carmelitarum Discalceatorum, Romae 1933, vol. VIII, fasc. 2.

Buszewicz E., Sarmacki Horacy i jego liryka: imitacja, gatunek, styl: rzecz o poezji Macieja Kazimierza Sarbiewskiego, Kraków 2006.

Crisógono de Jesús Sacramentado, San Juan de la Cruz. Su obra científicay su obra literaria, t. 2, Avila 1929.

GiL Cz., Karmelici bosi w Polsce 1605-1655, „Nasza Przeszłość” 48 (1977).

Historia literatury, red. J. Ziomek, Warszawa 1956.

HoLmes J.S., The name and nature of translation studies, w: The Translation Studies Reader, red. L. Venuti, London-New York 2004.

Janicki W., Humanizm i sarmatyzm w mitologii i rzeczywistości historycznej. Przeciw uproszczeniom, „Życie i Myśl”1984, nr 3.

Literatura i instytucje w dawnej Polsce, red. H. Dziechcińska, Warszawa 1994.

Nadolski B., Poezja polska epoki Odrodzenia, w: Odrodzenie w Polsce. Materiały sesji naukowej PAN 25-30 IX 1953, t. 4, Warszawa 1956.

Niesiecki K., Herbarz polski, t. 2, Lipsk 1839.

59 J. Kochanowski, Monomachija Parysowa z Menelausem, Warszawa 2012, s. 124. 
Opera Mystica Venerabili ac Mystici Doctoris F. Joannis a Cruce..., Coloniae 1639.

Orozco DíAz E., Estudios sobre San Juan de la Cruz y la mística del barroco, t. 1, Granada 1994.

Philippus a SS. Trinitate, Decor Carmeli religiosi, Lugduni 1665.

SAn Juan de la Cruz, Obraz completas, Madrid 1988.

Sinko T., Historia poezji tacinskiej humanistycznej w Polsce, w: Dzieje literatury pięknej w Polsce, red. S. Tarnowski, Kraków 1918.

Sinko T., Literatura polsko-łacinska. Problemy i zadania, „Eos” XLV (1951), fasc. 2. Społeczeństwo staropolskie. Studia i szkice, red. A. Wyczański, t. 2, Warszawa 1980.

STAWECKa K., Maciej Kazimierz Sarbiewski - prozaik i poeta, Lublin 1989.

Św. JaN OD Krzyża, Dzieła, tłum. B. Smyrak, Kraków 2014.

Św. Jan od Krzyża, Pieśń duchowa, tłum. C. Marrodán Casas, M. Kurek, Kraków 2017.

ULEWIECz T., Sto lat badań filologicznych nad tacińska twórczościa humanistyczno-renesansowa w Polsce, w: Wokót Kochanowskiego i jego czasów. Materiaty sesji naukowej poświęconej kulturze literackiej Małopolski w dobie renesansu. Kielce, 10-11 października 1992, red. M. Garbaczowa, Kielce 1994.

VENuTi L., The Scandals of Translation: Towards an ethics of difference, London-New York 1998.

ZabŁocki S., Od prerenesansu do oświecenia. Z dziejów inspiracji klasycznych w literaturze polskiej, Wrocław 1976.

Zabєocki S., Poezja polsko-łacińska wczesnego renesansu. Wybrane zagadnienia, w: Problemy literatury staropolskiej, seria 2, red. T. Pelc, Wrocław 1973.

Z ABєOCKI S., Polsko-tacinskie epicedium renesansowe na tle europejskim, Wrocław 1968.

\begin{abstract}
DAMIAN SOCHACKI, OCD

The Neolatin Translation of the Works of St John of the Cross in Context of Renaissance and Baroque Latinitas in Europe
\end{abstract}

The author focuses on issues relate to Neolatin translations, illustrating the basic assumptions of the so-called Jesuit baroque translation of the works of St John of the Cross, prepared by Andrzej Brzechwa (1584-1640), the first Polish Discalced Carmelite. Latin translations from vernacular languages became popular as early as the end of the Middle Ages, e.g. Giovanni Boccaccio's The Decameron, thanks to its translations in prose and verse into the Romans' language, found readers all over Europe. Brzechwa's translation was in many respects a pioneering work, but it has 
not been scientifically reviewed yet. Although it does follow the extremist assumptions of Latin Baroque poetry (pure style, classical vocabulary), its rich workshop and preparation are laudable: an example may be the equivalent of the popular Spanish stanza proposed by Brzechwa: the so-called lyre in the form of the classic Sapphic stanza. This article, after a brief review of the distinctive features of Neolatin literature of the $17^{\text {th }}$ century, analyses the grammatical and rhetorical layers of Brzechwa's translation. It presents strategies for translating key phrases of the prose and poetry of St John of the Cross, comparing Brzechwa to one of the greatest representatives of Polish Latin Baroque, Maciej Kazimierz Sarbiewski (1595-1640).

Keywords: Andrzej Brzechwa, translation, Latin, John of the Cross, Baroque

Słowa klucze: Andrzej Brzechwa, przekład, łacina, Jan od Krzyża, barok 